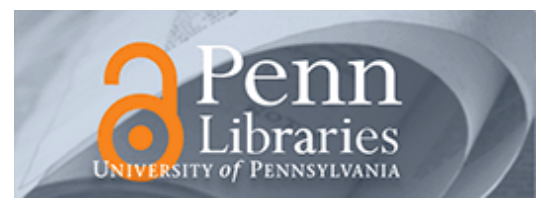

University of Pennsylvania

ScholarlyCommons

Real Estate Papers

Wharton Faculty Research

$7-2004$

\title{
The Asset Price Incidence of Capital Gains Taxes: Evidence From the Taxpayer Relief Act of 1997 and Publicly-Traded Real Estate Firms
}

Todd Sinai

University of Pennsylvania

Joseph Gyourko

University of Pennsylvania

Follow this and additional works at: https://repository.upenn.edu/real-estate_papers

Part of the Public Economics Commons, Real Estate Commons, and the Taxation Commons

\section{Recommended Citation}

Sinai, T., \& Gyourko, J. (2004). The Asset Price Incidence of Capital Gains Taxes: Evidence From the Taxpayer Relief Act of 1997 and Publicly-Traded Real Estate Firms. Journal of Public Economics, 88 (7-8), 1543-1565. http://dx.doi.org/10.1016/S0047-2727(03)00036-7

This paper is posted at ScholarlyCommons. https://repository.upenn.edu/real-estate_papers/25

For more information, please contact repository@pobox.upenn.edu. 


\title{
The Asset Price Incidence of Capital Gains Taxes: Evidence From the Taxpayer Relief Act of 1997 and Publicly-Traded Real Estate Firms
}

\begin{abstract}
We provide new evidence on the asset price incidence of corporate-level investment subsidies by examining the relative stock price performance of publicly traded companies in the real estate industry that should have been differentially affected by the capital gains tax rate reduction enacted in the Taxpayer Relief Act of 1997. By comparing real estate firms that have an organizational structure that allows entities who sell property to it to defer capital gains taxes and that plan to use the structure to acquire property with those that do not, we isolate the effect of the tax cut from industry trends and firmlevel heterogeneity. When we examine the time period surrounding the reduction in the capital gains tax rate, our results suggest the tax change was substantially capitalized into lower share prices for these firms and the benefit of the seller's capital gains tax deferral accrued mainly to the buyer of an appreciated property.
\end{abstract}

\section{Keywords}

tax incidence, tax capitalization, REITS

\section{Disciplines}

Public Economics | Real Estate | Taxation 
NBER WORKING PAPER SERIES

\title{
THE ASSET PRICE INCIDENCE OF CAPITAL GAINS TAXES: EVIDENCE FROM THE TAXPAYER RELIEF ACT OF 1997 AND PUBLICLY-TRADED REAL ESTATE FIRMS
}

\author{
Todd Sinai \\ Joseph Gyourko \\ Working Paper 7893 \\ http://www.nber.org/papers/w7893 \\ NATIONAL BUREAU OF ECONOMIC RESEARCH \\ 1050 Massachusetts Avenue \\ Cambridge, MA 02138 \\ September 2000
}

This research was supported by the Research Sponsor Program of the Zell/Lurie Real Estate Center at The Wharton School of the University of Pennsylvania. Donghoon Lee provided outstanding research assistance. We are grateful to Merle Erickson, Bill Gentry, Will Goetzmann, Owen Lamont, Chris Leach, Ed Maydew, Chris Mayer, Barbara Murray, Doug Shackelford, Reed Shuldiner, Nick Souleles, Joel Waldfogel, and seminar participants at Columbia University Graduate School of Business, the Homer Hoyt Institute, the University of Colorado, the University of Florida, UCLA, the UNC Tax Symposium, the University of Pennsylvania, and the National Bureau of Economic Research for helpful comments and discussions. The views expressed herein are those of the authors and not necessarily those of the National Bureau of Economic Research.

(C) 2000 by Todd Sinai and Joseph Gyourko. All rights reserved. Short sections of text, not to exceed two paragraphs, may be quoted without explicit permission provided that full credit, including $\odot$ notice, is given to the source. 
The Asset Price Incidence of Capital Gains Taxes: Evidence from the Taxpayer Relief Act of 1997 and Publicly-Traded Real Estate Firms

Todd Sinai and Joseph Gyourko

NBER Working Paper No. 7893

September 2000

JEL No. H22, H25, G14, G32, G12

\section{$\underline{\text { ABSTRACT }}$}

We provide new evidence that corporate-level investment subsidies can be substantially capitalized into asset prices by examining the relative stock price performance of publicly traded companies in the real estate industry that should have been differentially affected by the capital gains tax rate reduction enacted in the Taxpayer Relief Act of 1997. By comparing real estate firms that have an organizational structure that allow property sellers to defer capital gains taxes and plan to use it to acquire property with those that do not, we isolate the effect of the tax cut from industry trends and firm-level heterogeneity. When we examine the time period surrounding the reduction in the capital gains tax rate, our results suggest the tax change was substantially capitalized into lower share prices for these firms and that the benefit of the seller's capital gains tax deferral accrued mainly to the buyer of an appreciated property. The validity of our estimation strategy is supported by further tests showing that these firms did not experience any relative movement in share prices during the previous year when capital gains tax rates did not change.

Todd Sinai

Wharton School

University of Pennsylvania

308 Lauder-Fischer Hall

256 South 37 th Street

Philadelphia, PA 19104-6330

(215) 898-5390

and NBER

sinai@wharton.upenn.edu
Joseph Gyourko

Wharton School

University of Pennsylvania

313 Lauder-Fischer Hall

256 South 37 th Street

Philadelphia, PA 19104-6330

(215) 898-3003

gyourko@wharton.upenn.edu 
Models of tax incidence predict that the tax treatment of the return on an asset should affect the price of that asset to an extent determined by the relative elasticities of demand and supply for the asset. While the theoretical underpinnings of these models are well-developed [Summers (1981), Poterba (1984)], empirical evidence of the effect of taxes on asset prices when the asset in question is a company is less complete. In contrast to the more extensive, but still inconclusive, empirical literature on the extent to which shareholder-level dividend and capital gains taxes are capitalized into share prices, relatively little empirical research addresses the issue of how or whether corporate-level taxes or investment subsidies affect share prices. However, this issue is of intrinsic interest as the economic incidence of these subsidies is not clear a priori. For example, a company that is eligible for a subsidy may not receive the full benefit as some may accrue to the suppliers of the investment good. The relative paucity of work in this area arises from the difficulty in estimating an empirical relationship when there often is not much variation among companies in their corporate tax rates and, if there is, it typically is endogenously driven by other important characteristics of the companies.

We provide new evidence that corporate investment subsidies can be substantially capitalized into share prices by examining the relative stock price performance of publicly-traded companies that should have been differentially affected by the capital gains tax rate reduction enacted in the Taxpayer Relief Act of 1997. By lowering the personal capital gains tax rate, the 1997 legislation potentially raised the relative price of investment for some firms in the real estate industry. These particular firms, called umbrella real estate partnership trusts, or UPREITS, have a corporate structure that enables entities that sell properties to the firm to defer or avoid paying capital gains taxes. To the extent that UPREITs are able to capture some of the benefit associated with the tax deferral by paying lower prices for properties, the decrease in capital gains tax rates in 1997 reduced a subsidy to investment for these 
companies. Regular real estate investment trusts, called REITs, do not have a corporate structure that permits sellers to defer gains taxes, so the relative price of investment they face should not have been affected by the tax change.

When we examine the time period surrounding the reduction in the capital gains rate, our results suggest that the tax change was substantially capitalized into lower share prices for UPREITs. We isolate the effect by comparing the difference in UPREIT share price growth before and during the change in the tax code to the change in returns for regular REITs. We also distinguish acquisitive UPREITs -- those companies that intended to buy properties on an ongoing basis and thus the only ones that should benefit from an investment subsidy -- from nonacquisitive UPREITs which should not have been affected by the tax change. We find that stock prices for acquisitive UPREITs fell when capital gains tax rates were reduced in 1997: their share price growth around the passage of TRA97 was 14 percent lower than for non-acquisitive UPREITs when compared to the difference in returns for acquisitive and non-acquisitive REITs and baselined against the relative performances of the four types of real estate companies in 1996 when there was no tax change. As we show below, this result indicates both that UPREITs, not building sellers, reaped most of the benefit of the gains tax deferral and that the investment subsidy was substantially capitalized into UPREIT share prices. However, while we can statistically reject the null hypothesis of no effect on share price, we cannot distinguish between full and partial capitalization.

Due to our research design comparing the returns of acquisitive UPREITs to non-acquisitive UPREITs and to acquisitive and non-acquisitive REITs, our result is quite robust. Since both UPREITs and REITs are real estate companies and invest in similar property sectors, they form a natural basis for comparison. For example, the comparison effectively eliminates the impact of any event that affected 
the real estate market in general, such as an increase in property prices, because it would affect UPREIT and REIT returns the same way. The effects of other factors that might only affect UPREIT returns, such as conflicts of interest inherent in the structure, are eliminated by comparing acquisitive and non-acquisitive UPREITs. Differences in market performance for acquisitive real estate firms are controlled for by comparing acquisitive UPREITs and REITs. And, we account for the possibility that each of the four types of companies has a different trend growth rate by comparing 1996 returns to 1997.

The validity of our estimation strategy is supported when we repeat the analysis for 1995 and 1996. In those years when there were no relevant tax changes, we find no difference in relative returns for acquisitive UPREITs. Finally, incorporating other explanatory variables that might explain differences in returns between companies such as dividend yield, beta, or the Fama-French factors does not significantly affect the estimated effect of the 1997 tax change.

Our finding of substantial effects of the tax change on share prices contrasts with other empirical research on the asset price incidence of corporate-level taxes and subsidies. Goolsbee (1998) studied changes in the investment tax credit and concluded that much of the investment subsidy accrued to suppliers of capital goods, at least in the short run. Our results, while not directly analogous, show the opposite for buildings during our sample period. Cutler (1988) found limited asset price effects of the change in relative taxation of equipment and structures in the Tax Reform Act of 1986 and concluded that the market inefficiently prices tax information. However, his failure to find a stronger result could be due to the complexity of the tax reform or the effect simply being too difficult to distinguish with his data. While our focus on real estate limits comparability to Cutler's (1988) results for industrial corporations or Goolsbee's (1998) findings for equipment prices, we believe our cleaner identification is 
worth the trade off. Not only is real estate an important and understudied sector of the economy, ${ }^{1}$ but studies within business sectors may identify impacts that are masked in the averaging that results from cross-industry analyses. ${ }^{2}$

The rest of this paper proceeds as follows: Section 1 describes the REIT and UPREIT structures. In section 2, we provide an analytical framework that explains why UPREITs may receive a tax subsidy when they purchase appreciated property. The circumstances surrounding the Taxpayer Relief Act of 1997, which we use to identify our estimates, are outlined in section 3. Section 4 presents the empirical work and discusses the results. Section 5 concludes.

\section{Background on the REIT industry and the UPREIT structure}

In order to isolate the effect of a tax subsidy on share values, we focus on a specific set of corporations, equity real estate investment trusts (REITs), which are publicly-traded firms that own and operate properties. Unlike typical public corporations, REITs have elected a pass-through tax status under which they do not pay income or capital gains taxes at the corporate level as long as they pay out

\footnotetext{
${ }^{1}$ At the end of 1997, commercial real estate in the United States was valued at $\$ 3.8$ trillion and accounted for 28 percent of the assets of nonfarm, nonfinancial corporations, a fraction higher than that for equipment and inventories combined. See the Federal Reserve Board, Flow of Funds, publication Z.1, June 1998, p. 105.

${ }^{2}$ Much of the other research in this area is part of the related literature mentioned earlier on the capitalization of shareholder-level taxes into asset prices. Recently, Harris and Kemsley (1998), Harris, Hubbard and Kemsley (1999), and Gentry, Kemsley and Mayer (2000) revisit the issue of whether dividend taxes are capitalized into share prices. In another vein, Poterba and Weisbenner (1998) demonstrate that the particulars of the tax treatment of capital gains can influence end-of-the-year stock price dynamics. Lang and Shackelford (1999) use the same event as we do, the decrease in the capital gains tax rate in the Tax Reform Act of 1997, to investigate whether it influenced share prices since investors would receive a higher after-tax return. They find that over one week in April and May when a budget compromise was finally reached, share prices for firms that typically pay low dividends rose more than share prices for companies that pay high dividends, the latter's shareholders benefitting less from the cut in the capital gains rate. However, these strands of research examine the situation where an individual owns shares and is going to trade them later. Either there is some tax associated with the transaction, such as a capital gains tax, or, in the case of dividends, a personal tax associated with their receipt that may affect valuation. In our case, the focus of the analysis is not on personal taxation and its impacts, but on corporate-level effects. For us, the direct impact (if any) would be on the prices UPREITs pay for properties relative to REITs. Ultimately, this should affect relative firm performance because of the different after-tax costs of investing that are possible across the two different organizational structures.
} 
at least 95 percent of their taxable incomes in the form of dividends. ${ }^{3}$ Even though the legislation enabling REITs to be created was passed in 1960, only in the last decade has the industry seen much growth. The total market capitalization of all REITs was just over \$15 billion at year-end 1992, while five years later the figure had risen to $\$ 140$ billion in 176 firms.

Some real estate investment trusts have adopted a corporate structure known as an 'UPREIT' that confers particular capital gains tax benefits relative to traditional REITs. Unlike a regular REIT, which must pay for properties with cash or stock, an UPREIT's structure permits the issuance of operating partnership (OP) units in exchange for properties. Consequently, transferring buildings to a traditional REIT requires that the seller pay applicable capital gains taxes. However, transferring buildings to an UPREIT is not a taxable event as long as the seller receives OP units, not cash or stock, even though OP units are typically exchangeable one-for-one into common shares and pay the same dividend as common shares. In this case, the Internal Revenue Service (IRS) treats the latter type of deal as a tax-free exchange, with the building seller deferring her capital gains tax liability until either she converts her OP units into stock ${ }^{4}$ or the UPREIT sells the contributed properties. The appendix describes the UPREIT structure in more detail.

The creation of the first UPREIT by the Taubman Realty Group in December 1992 ushered in a wave of such firms. Figure 1 shows how many public real estate corporations were formed each year and whether they were traditional REITs or UPREITs. By December 1992, 40 traditional equity REITs existed. In 1993 and 1994, 66 new UPREITs held their initial public offerings while only 14 new

\footnotetext{
${ }^{3}$ There are several other criteria a company must satisfy before it is allowed to be treated as a REIT, but none are material to the analysis in this paper.

${ }^{4}$ Typically, a unitholder would not convert her units unless she planned to sell the stock. If the original building seller dies before converting the units, the tax basis is stepped-up.
} 
traditional REITs did so. The numbers of new UPREITs declined substantially in 1995 and they are now being created at roughly the same rate as traditional REITs. ${ }^{5}$

\section{Analyzing the value of the UPREIT structure and the role of capital gains taxes}

Because real property is depreciated for tax purposes, the proportion of the asset value that is considered a capital gain can be quite large. Hence, being able to defer, or even avoid, capital gains taxes by selling a property to an UPREIT potentially could convey a sizeable benefit that property sellers and/or property buyers (UPREITS in this case) could reap. UPREITs can benefit if the prices they pay for properties are lower than would be the case otherwise or if their ability to obtain properties is greater because sellers treat avoiding the capital gains tax as part of their compensation. If this is the case to any extent, the UPREIT shares in the benefit even though it is the property seller who legally gets to defer paying the tax. To an UPREIT, the capital gains tax may appear to be a subsidy similar to an investment tax credit, lowering the prices they pay for properties and increasing the yield. The size of the subsidy will depend on the value to the property seller of the tax deferral -- which increases with the capital gains tax rate -- and the proportion of that value that is reflected in lower property prices. In the remainder of this section, we first outline the benefit a property seller could obtain by selling to an UPREIT and then describe how we isolate the effect of the benefit on UPREIT share prices.

By selling to an UPREIT, a property owner trades off the benefit of deferring or avoiding capital gains taxes with being locked in to holding the UPREIT's OP units. The expected value of this choice in today's dollars is the sale price minus the future capital gains tax liability, plus the expected after-tax return from investing in the UPREIT by holding OP units, all discounted to the present. Defining $V_{U}$ and

\footnotetext{
${ }^{5}$ Ten companies switched from being traditional REITs to UPREITs after 1992 and are excluded from the chart. Many of those companies created what has been labeled a 'downREIT,' creating an operating partnership to purchase specific properties while the REIT continues to own the original properties. Unlike the UPREIT form, the downREIT structure does not have the explicit blessing of the IRS.
} 
$V_{R}$ as the current prices UPREITs and REITs respectively are willing to pay for the building, $\psi$ as the proportion of the building sold for OP units rather than cash or stock, $H$ as the seller's expected holding period of the OP units, $r_{\text {REIT }}$ as the annual pre-tax return to an UPREIT OP unit, $\delta$ as the proportion of that return paid out as dividends, $\tau_{\mathrm{C}}$ as the capital gains tax rate and $\tau_{\mathrm{DIV}}$ as the rate on dividend income, $r$ as the equivalent-risk after-tax opportunity return, and assuming tax rates are expected to remain constant, the expected total after-tax proceeds from a sale to an UPREIT would be:

$$
S_{U P R E I T}=\psi\left[\frac{V_{H}-\tau_{C}\left(V_{H}-B\right)}{(1+r)^{H}}\right]+\sum_{t=1}^{H} \frac{V_{U}\left(1+(1-\delta) r_{R E I T}\right)^{t-1} \cdot \delta \cdot r_{R E I T}\left(1-\tau_{D I V}\right)}{(1+r)^{t}}-(1-\psi)\left(V_{R}-\tau_{C}\left(V_{R}-B\right)\right)(1)
$$

The first term (in brackets) reflects that both the cash flow from the sale and the capital gains tax payment are deferred for $H$ years. Since the original property owner is selling the units farther in the future, she receives a higher price, $V_{H}=V_{U}\left(1+(1-\delta) r_{R E I T}\right)^{H}$, that includes the expected capital gain in the OP units. The capital gains tax (at unchanged rate $\tau_{\mathrm{C}}$ ) must be paid on the entire capital gain, $\mathrm{V}_{\mathrm{H}-\mathrm{B}}$, rather than $\mathrm{V}_{\mathrm{U}}-\mathrm{B}$, but it does not need to be paid for $H$ years. ${ }^{6}$

The second term starting with the summation sign values the discounted cash flow from the stream of dividend payments. The REIT generates a return of $r_{\text {REIT }}$ every year on the current equity value of the company, $\delta$ percent of which is paid out as dividends and taxed at the rate $\tau_{\text {DIV. }}$. The remainder of the return, $(1-\delta) r_{\text {REIT }}$, is retained by the company and creates capital appreciation. The stream of dividend payments increases over time, with the dividend yield remaining constant by assumption and the equity value of the company increasing due to capital gains. All lump sums and flows are discounted at the after-tax opportunity cost rate, $r$.

\footnotetext{
${ }^{6}$ The Taxpayer Relief Act of 1997 instituted a two-part capital gains tax on real properties. Gains due to appreciation, $\mathrm{V}_{0}$ minus the purchase price, $\mathrm{PP}$, are taxed at a 20 percent rate while gains due to depreciation, $\mathrm{PP}-\mathrm{B}$, are taxed at 25 percent. We abstract from this detail in this section.
} 
The alternative to selling to an UPREIT is to sell the property for cash or stock. This option is the only one available if a REIT is the purchaser. In that case, all capital gains taxes must be paid at the time of the transaction. For the seller, the after-tax sale value is $S_{R E I T}=V_{R}-\tau_{C}\left(V_{R}-B\right)$.

The net benefit of selling to an UPREIT, SUPREIT $-\mathrm{S}_{\mathrm{REIT}}$, increases with the capital gains tax rate, the proportion of sales price paid in OP units, expected time before selling the units, and the discount rate, but decreases when the basis or opportunity cost of holding OP units rise. Denoting the summation term in (1) as $K$, the difference between selling to an UPREIT and to a REIT is:

$$
S_{\text {DIFF }}=S_{\text {UPREIT }}-S_{R E I T}=\psi\left[\left(\tau_{C}\left(V_{R}-B\right)-\frac{\tau_{C}\left(V_{U}-B\right)}{(1+r)^{H}}\right)-\left(V_{R}-\frac{V_{U}}{(1+r)^{H}}\right)+\left(\frac{\left(1-\tau_{C}\right)\left(V_{H}-V_{U}\right)}{(1+r)^{H}}\right)+K\right] \text { (2) }
$$

The first term in brackets now reflects the lowered tax cost achieved by deferring the capital gains tax liability: the building seller is able to invest the tax for $H$ years instead of paying it to the government today. Offsetting that benefit is the second term which measures the loss in value from not receiving the cash value of the building for $H$ years as well. However, that value, $\mathrm{V}_{\mathrm{U}}$, is invested in the UPREIT and yields a discounted after-tax return that is accounted for in the last two terms: the after-tax value of the capital appreciation in the UPREIT units plus the discounted value of the after-tax dividend payments.

The difference in after-tax prices received by the building seller is also affected by the relative pre-tax prices paid by REITs and UPREITs, $\mathrm{V}_{\mathrm{R}}$ and $\mathrm{V}_{\mathrm{U}}$. By paying less for properties, REITs and UPREITs can increase their returns. If competition among REITs and UPREITs for acquisitions raises property prices until all firms are just making their (common) required rate of return, then $V_{R}=V_{U}$ and the entire benefit of the capital gains tax deferral accrues to those sellers who sell to UPREITs. However, if competition among property owners to sell buildings makes them willing to accept a lower after-tax price, UPREITs conceivably could capture up to the entire value of the capital gains tax 
deferral since they can reduce $V_{U}$ below $V_{R}$ until the after-tax benefit of selling to an UPREIT or REIT is almost identical. ${ }^{7}$

Before proceeding to estimate the extent to which the capital gains tax deferral is reflected in UPREIT share prices, it is useful to gauge how much capitalization one could expect to find. We begin with a baseline calculation of the potential reduction in prices paid by UPREITs for properties due to the capital gains tax deferral. To simplify the example, we assume the building seller would have invested her proceeds in UPREIT units whether or not she sold to the UPREIT. In that case, which yields an upper bound on the value of the structure, $V_{U}=\left[\left(1-\tau_{C}\right)\left(V_{H}-V_{U}\right)+V_{U}\right] /(1+r)^{H}$ and thus $V_{R}=\frac{V_{U}-\tau_{C} B}{1-\tau_{C}}-\left(\frac{\tau_{C}}{1-\tau_{C}}\right)\left(\frac{V_{U}-B}{(1+r)^{H}}\right)$. The difference between $V_{\mathrm{R}}$ and $V_{\mathrm{U}}$ is maximized when the capital gains basis is zero and the holding period is infinite (corresponding to capital gains tax avoidance, such as holding the OP units until death). ${ }^{8}$ Thus, the most favorable outcome for UPREITs is that they pay $1-\tau_{\mathrm{C}}$ less than REITs per dollar of property they obtain using OP units. Using this formula, the capital gains tax rate reduction from 28 to approximately 21 percent in the Taxpayer Relief Act of 1997, discussed in more detail in the next section, lowered the potential subsidy to UPREITs by about

\footnotetext{
${ }^{7}$ If the building sellers were willing to take a minimum after-tax return, REITs would have to pay a premium to

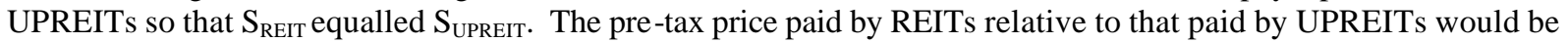
$V_{R}=\left(\frac{1}{1-\tau_{C}}\right)\left(\frac{V_{H}-\tau_{C}\left(V_{H}-B\right)}{(1+r)^{H}}\right)+\frac{K-\tau_{C} B}{1-\tau_{C}}$.

${ }^{8}$ Although properties are likely to have a positive tax basis, in reality we suspect the average basis on properties sold to UPREITs is low. Even though land is not depreciable, given the accelerated depreciation available on properties in place before 1987 and the considerable benefit to depreciating properties as fast as possible the structures easily could be fully or nearly fully depreciated. Also, one would expect that sellers with high capital gains would be most likely to sell to UPREITs. Also, the building seller may not expect to hold the OP units until death, reducing H. We do not think this is a significant issue. If necessary, a rational OP unit holder would find some way to extract cash from the units or diversify them without incurring the expensive tax cost of selling. For examples of tax-efficient portfolio strategies, see Constantinides (1983) and Stiglitz (1983). Moreover, the tax subsidy is not particularly sensitive to the length of holding period.
} 


\section{7 percent. $^{9}$}

The next step is to calculate the potential effect of lower property acquisition prices on UPREIT share prices. While it is less direct to empirically back out capitalization effects using share prices, commercial property price data is notoriously noisy and commercial property characteristics are poorly measured. Share price data quality is much higher because share prices are measured accurately and capture expectations, and company-level characteristics are usually reported. Thus we will examine share prices in this paper. ${ }^{10}$

When calculating the potential cost to UPREITs of a capital gains tax cut, we want to capture the likelihood that those UPREITs intending to acquire more properties benefit more from the tax subsidy. Writing the expected present value of the rental stream on currently owned properties as $E[R]$ and the expected net rents from future acquisitions as $\mathrm{E}[\mathrm{A}]$, the stylized market value of firm $i$ of type $k$ $(k=\mathrm{REIT}$ or UPREIT $)$ is $\mathrm{V}_{\mathrm{it}}=\lambda\left(\mathrm{E}[\mathrm{R}]_{\mathrm{it}}+\mathrm{E}[\mathrm{A}]_{\mathrm{it}}\right)+\mathrm{X}_{\mathrm{it}}+\eta \mathrm{t}_{\mathrm{k}}+\mu_{\mathrm{i}}$, where $\mathrm{X}$ is a vector of potentially timevarying firm-level characteristics such as the dividend payout strategy, $\eta \mathrm{t}$ is a time-trend that is common within REITs and UPREITs, and $\mu$ corresponds to other firm-level characteristics that do not vary over time. The first term, $\lambda$, scales up the present values to account for the effect of leverage. To eliminate the impacts of $\mu$, such as potential conflicts of interest inherent in the UPREIT structure leading to lower valuations, we will examine growth in $\mathrm{V}$, decomposing it into the weighted average percent changes in

\footnotetext{
${ }^{9}$ If they reaped all the benefit of the capital gains tax avoidance, UPREITs paid $\$ 1-\tau_{\mathrm{C}}$, or $\$ 0.72$, for every dollar's worth of real estate purchased with OP units before 1997 while REITs paid a full dollar. After TRA97, UPREITs paid $\$ 1-\$ 0.21$, or $\$ 0.79$, while REITs still paid a dollar. The statutory tax treatment for REITs did not change at all while the subsidy to UPREITs fell by $(0.72-0.79) /(0.72)$ or 9.7 percent. In this example, we assume that a weighted average of the appreciation and depreciation components of capital gains yielded an effective post-TRA97 tax rate of 21 percent.

${ }^{10}$ In an earlier version of this paper, we tried examining the effect on acquisition prices. Comparing the prices paid by UPREITs relative to REITs before and after the change in capital gains tax rates yielded results consistent with our hypothesis that UPREITs bore the economic incidence of the ability to defer gains taxes on property acquisitions. However, the point estimates were imprecisely measured and the implied capitalization into property prices was so large in some cases that we suspect the underlying data had too much noise to generate convincing results.
} 
expected revenue from current and future properties:

$$
\% \Delta V_{i t}=\lambda\left[\frac{E[R]_{i t}}{V_{i t}} \cdot \% \Delta E[R]_{i t}+\frac{E[A]_{i t}}{V_{i t}} \cdot \% \Delta E[A]_{i t}\right]+\frac{X_{i t}}{V_{i t}} \cdot \% \Delta X_{i t}+\eta_{k}^{\prime}
$$

Since changes in the capital gains tax rate may lead to differences in acquisition prices for UPREITs, they should affect market value more for UPREITs than for REITs. ${ }^{11}$ The share price of more acquisitive UPREITs -- who have a higher proportion of their value due to expected growth through property purchases, $\mathrm{E}[\mathrm{A}] / \mathrm{V}$-- should be more sensitive to capital gains tax changes, as a change in personal capital gains rates should not affect the expected rent stream on current properties or the impact of other covariates. Thus, the effect on $\mathrm{V}$ should be an increasing function of the weighting of future acquisitions in the market value of the company, $\mathrm{E}[\mathrm{A}] / \mathrm{V}$.

Our earlier calculation of a potential 9.7 percent increase in acquisition prices for UPREITs whose properties are completely financed with OP units, implies that yields on new properties, E[A], will fall by the same amount. ${ }^{12}$ The largest effect would be found if all of acquisitive UPREITs' value were due to future acquisitions, so that $\mathrm{E}[\mathrm{A}] / \mathrm{V}=1$. The capitalization into share value for acquisitive UPREITs, then, would be 9.7 percent times the leverage scaling factor. The debt-to-value ratio for a typical UPREIT has been about 40 percent. That level of leverage would cause the reduction in return to be magnified by about 150 percent for the average UPREIT. ${ }^{13}$

\footnotetext{
${ }^{11}$ Competition between REITs and UPREITs provides another potential avenue for differential effects on performance. If UPREITs can acquire more of the available properties than REITs due to the tax subsidy, REITs may find their growth opportunities curtailed, leading to a lower value. Our empirical work will capture this mechanism since we will be concerned only with the relative share price movements of REITs and UPREITs.

${ }^{12}$ To the extent that rents are higher because investment in properties declines with the tax change, the effect will be the same for UPREITs and REITs.

${ }^{13}$ We calculated this scaling factor using the market capitalization weighted average values for UPREITs in 1997. Debt was assumed to cost the same as A-grade CMBS, which traded at 100 basis points above the 10-year Treasury rate of 6.35 percent. Given the typical implicit cap rate in 1997, a \$13.6 million building would generate \$1 million in
} 
Other factors besides leverage could increase the estimated capitalization. Investors could perceive the current tax change as a signal of future changes. Also, the tax basis for a property could respond to the tax change, with property owners not accumulating as much appreciation before selling their buildings when the tax rate falls. This secondary effect of a lower capital gain on the building at sale further reduces the subsidy and magnifies the measured effect. Similarly, the holding period for OP units might fall after the tax change since the cost of selling the shares is less. ${ }^{14}$

In order to isolate the effect of a capital gains tax change on UPREIT share prices from all the factors embodied in equation (3), we note that many of these factors are common between the average REIT or UPREIT and acquisitive or non-acquisitive company, or are unchanging over time. For example, the proportion of firm value due to rents from existing properties, $E[R] / V$, will be the same among acquisitive companies and among non-acquisitive companies. The growth in rents and the effect of real estate market movements in prices and rents on $\mathrm{E}[\mathrm{A}]$ will be common across all REITs and UPREITs. The REIT or UPREIT growth trend, $\eta$, is assumed to be constant over time. In order to eliminate these common factors and obtain the effect of the capital gains tax change alone, we difference the average share price growth over time and across organizational structures:

$$
\begin{gathered}
\% \Delta \bar{P}=\left(\left(\% \Delta \bar{P}_{U P R E I T, A C Q, t}-\% \Delta \bar{P}_{R E I T, A C Q, t}\right)-\left(\% \Delta \bar{P}_{U P R E I T, N O N, t}-\% \Delta \bar{P}_{R E I T, N O N, t}\right)\right)- \\
\left(\left(\% \Delta \bar{P}_{U P R E I T, A C Q, t-1}-\% \Delta \bar{P}_{R E I T, A C Q, t-1}\right)-\left(\% \Delta \bar{P}_{U P R E I T, N O N, t-1}-\% \Delta \bar{P}_{R E I T, N O N, t-1}\right)\right)
\end{gathered}
$$

revenue in the second period. The equity return on that building is 7.35 percent $(1-(0.40 * 13.6 * 0.0735)) /(13.6 *(1-0.40))$. If the price of the building rose 10 percent to $\$ 14.96$ million because of a change in the capital gains tax rate, but the second period revenue remained at $\$ 1$ million, the equity yield would decline to about 6.24 percent $(1-(0.40 * 14.96 * 0.0735)) /(14.96 *(1-0.40))$. This reflects a 15.1 percent potential decline in the equity return when the price of the building rose only 10 percent.

\footnotetext{
${ }^{14}$ Another reason why the measured capitalization could be very large can be found in Klein (1999). He develops a general equilibrium model where the capital gains lock-in effect raises share prices for firms with greater embedded capital gains. A lowering of the capital gains tax rate would reduce the extent of lock-in, lowering share prices. Since UPREITs have higher embedded capital gains because the OP units carry over the basis from the property that was purchased, their share prices should fall more when the capital gains tax rate is lowered. Lansman and Shackelford
} 
where $P$ is share price and ACQ and NON refer to acquisitive and non-acquisitive companies, respectively. ${ }^{15}$

One can think about this identification strategy in the framework of the event study literature where the excess return for an asset is examined for a correlation with some announcement or incident. The typical dilemma is how to measure excess return. Often a market model is used; for example, Cutler (1988) defines excess return as the portion of a stock's return above that predicted by a CAPM model. The benefit of a market model is that it allows the econometrician to compare the performance of relatively dissimilar firms. However, in our case we have a set of similar firms that we believe vary primarily in their response to the capital gains tax change. In this situation, the best possible market model is to control for one type of firm's return using the return on the other type of firm. Excess return, in this case, would be defined as the UPREIT return net of the REIT return. Thus, by comparing acquisitive UPREIT returns to those of acquisitive REITs (all relative to non-acquisitive UPREITs and REITs), we control for market movements without having to explicitly incorporate other factors or the market return into our estimation. Given the uncertainty in finance surrounding what asset pricing model best explains returns, this reduces the amount of noise and the likelihood of spurious results in our estimation. The implicit assumption in this strategy, that acquisitive REITs really would perform exactly like acquisitive UPREITs in the absence of a capital gains tax change (when baselined against nonacquisitive UPREITs and REITs and previous years), can be tested and we do so in section IV. This identification strategy is similar to one that is well-known in the labor and public economics literatures

(1995) find empirical evidence of this effect using data on the leveraged buyout of a company.

\footnotetext{
${ }^{15}$ In our empirical work, controlling for firm leverage does not change our estimate of the effect of a capital gains tax change on share prices, suggesting that leverage does not vary systematically between acquisitive and nonacquisitive REITs and UPREITs.
} 
for identifying the effects of non-financial market events (for examples, see Gruber (1994), Gruber and Poterba (1994), and Eissa (1995)).

\section{Taxpayer Relief Act of 1997}

The Taxpayer Relief Act of 1997 (TRA97) lowered the top tax rate on capital gains due to appreciation from 28 to 20 percent for assets held more than 18 months. For capital gains due to depreciation, the tax rate only fell to 25 percent. There were no other changes in the legislation that should have affected UPREITs differently than REITs.

Ideally, there would be some identifiable day or week where Congress surprised everyone by creating and passing the tax rate change. Unfortunately, the capital gains tax provisions of TRA97 were the subject of speculation and debate for several months before the final passage of the legislation. Table 1 lists the series of events leading up to the enactment of the bill. Even in early February, newspapers were reporting that there was a possibility of a capital gains tax cut. However, throughout February, March, and into April, speculation remained as the Clinton Administration and Congressional Republicans fought over whether Clinton would agree to cuts in the top capital gains rate to 20 percent or lower. In mid- to late-April, the negotiations moved towards reducing the capital gains tax rate. On April 30, the Congressional Budget Office reduced its estimate of the forthcoming budget deficit, reportedly the last event that enabled the Administration to reach a compromise with the Republicans.

On May 3, a capital gains tax cut was announced, although the size of the cuts was still to be negotiated. On May 7, it was announced that whatever capital gains tax cuts were agreed to would take effect on that day.

Until early- to mid-June, Congress debated how much to cut various taxes. On June 14, the House Ways and Means committee endorsed a plan to cut the top capital gains tax rate to 20 percent 
and, except for a Clinton 'last stand' at the end of June, the next six weeks were spent nailing down the details of the bill that was finally passed on August 1.

\section{Estimating Incidence: Empirical Strategy and Results}

\section{a. Sample and Variable Construction}

To investigate whether the capital gains changes in TRA97 were capitalized into firm prices, we begin with a list of all 202 existing REITs as of the first quarter of 1998 from the SNL Datasource, a computerized data base that reports a wide variety of information on publicly-traded real estate companies culled from SEC filings and other sources. Table 2 shows how this sample ultimately is reduced to 129 companies. ${ }^{16}$ We also obtained a variety of corporate characteristics from SNL such as whether the company used the UPREIT form, dividends declared each year, property focus, the date of the initial public offering, several measures of company size, and measures of institutional and insider ownership.

This firm information is then matched to daily stock price data for 1995, 1996, and 1997 from the Center for Research in Securities Prices (CRSP) database. The price variable used is the average of the closing bid-ask prices, with the daily price averaged over the relevant month before constructing the percent growth in share price. Thus, the left-hand-side variable in the specifications

\footnotetext{
${ }^{16}$ Forty-six companies were created during or after our 1996-1997 sample period and had to be discarded. Two other firms were discarded because no stock price information could be obtained for them. Of the remaining 154 companies, 12 were mortgage or hybrid REITs. Since those types of REITs perform quite differently than equity REITs, they are not an appropriate comparison for UPREITs and were dropped from the sample. Finally, eleven REITs adopted either an UPREIT structure or a close substitute, the downREIT structure, during our sample period. Because our estimation strategy requires that the UPREIT form be exogenous during the period of analysis, we dropped those firms that switched structure in 1996 or 1997. Removing the switchers can create a bias in that REITs may endogenously decide not to switch to the UPREIT form. The most plausible scenario would be that high growth REITs switch to UPREIT status. Since we delete the switchers, the remaining pool of REITs would be laggards and would have lower growth over time. This bias would work against us finding any capitalization.
} 
reported below is $\% \Delta P=\ln \bar{P}_{1}-\ln \bar{P}_{0}$ where 0 and 1 refer to calendar months. ${ }^{17}$ Taking the monthly average captures large, fundamental movements in share prices while minimizing sensitivity to the start date by reducing contamination from daily price fluctuations. Regressions are weighted by market capitalization at the beginning of the sample period, computed by multiplying the shares outstanding by the share price as reported by CRSP.

Equation (3) shows that, all else equal, UPREITs that derived more of their market value from planned property acquisitions should have been more adversely affected by the capital gains tax cut. Consequently, we divide companies into one of two categories based upon how 'acquisitive' they were in 1995. Since one cannot measure expected acquisitions directly, we replace E[A]/V with $1-E[R] / V$. We proxy for expected rent with 1995 total rental revenue, choosing that year because it was before our sample period. The denominator $V$ is 1995 firm value (debt plus equity). Since a company with low $\mathrm{E}[\mathrm{R}] / \mathrm{V}$ must have high $\mathrm{E}[\mathrm{A}] / \mathrm{V}$, companies with rent-to-value ratios below the weighted median are deemed the most acquisitive. Using this metric, we find that acquisitive companies are just as likely to be REITs as UPREITs: 49 percent of the highly acquisitive group, and nearly 65 percent of the leastacquisitive group, are UPREITs.

\section{b. Empirical Approach and Basic Specification}

Due to the long gestation period of TRA97, share prices before the legislation was discussed are compared to prices after the bill was passed. This ensures that we measure the change in price between a period when the tax cut was completely unexpected and when it was known with certainty. Even if we could identify that one of the series of tax-related events was a 'surprise,' it is impossible to know how much information was actually revealed during that period. Although comparing returns over a multiple-month time frame increases the possibility of spurious correlation with some other event, our

\footnotetext{
${ }^{17}$ Dividend flows are so stable that using total return on the left-hand-side, which we compute as $\%$ RET $=\left(P_{t}-P_{s}+(\right.$ annualdividend $\left.) \cdot(t-s) / 12\right) / P_{s}$, where $t$ and $s$ correspond to specific months, makes no difference in the results.
} 
research design controls for non-tax factors that affect the overall REIT industry or UPREITs versus REITs more specifically.

To estimate equation (4), we rewrite it in deviations form and run the following regression:

$$
\begin{gathered}
\% \Delta \bar{P}_{t 1-t 0, i t}=\alpha+\beta_{1} \cdot \text { UPREIT }_{i}+\beta_{2} \cdot Y 1997_{t}+\beta_{3} \cdot \text { UPREIT } \times Y 1997_{i t}+ \\
\beta_{4} \cdot \text { Acquisitive }_{i}+\beta_{5} \cdot \text { Acquisitive } \times Y 1997_{i t}+\beta_{6} \cdot \text { Acquisitive } \times U P R E I T_{i}+ \\
\beta_{7} \cdot \text { Acquisitive } \times \text { UPREIT } \times Y 1997_{i t}+\beta_{8} \cdot X_{i t}+\varepsilon_{i t}
\end{gathered}
$$

where the left-hand-side variable is the percent growth in the average share price of company $i$ from period 0 to period 1 in year $t$. UPREIT is an indicator variable for whether the company is an UPREIT, Acquisitive is another indicator variable for whether the company is expected to be in property acquisition mode, and Y1997 takes a value of one if the year is 1997, X is a vector of covariates that may affect the relative growth rate of real estate companies over time, and all other variables are interactions of these terms.

The estimated coefficient, $\beta_{1}$, will measure the additional return to the UPREIT structure relative to REITs in 1996, $\beta_{2}$ corresponds to the average additional return to REITs in 1997 relative to 1996, and $\beta_{4}$ reflects the mean return differential to high property acquisition companies in 1996 . The interaction terms capture a variety of relative price appreciation changes over time and across types of firms. For example, $\beta_{3}$ is our estimate of the percent change in UPREIT share price growth relative to REITs between 1996 and 1997. Analogously, $\beta_{5}$ measures the percent change in acquisitive firm share price growth relative to non-acquisitive firm share price growth between 1996 and 1997. The mean additional return to acquisitive UPREITs in 1996 is reflected in the estimate of $\beta$.

Of most interest for us is the $\beta_{7}$ coefficient, as it captures the extent to which acquisitive UPREITs appreciated differently in 1997 versus 1996, relative to non-acquisitive UPREITs and to acquisitive and non-acquisitive REITs. As suggested above, if UPREITs do capture some or all of the 
benefit of the tax deferral we would expect the impact of TRA97 to be capitalized into acquisitive UPREIT prices that year, yielding a significantly negative estimated coefficient.

\section{c. Summary Statistics and Results}

Table 3 presents summary statistics on key variables used in the analysis. Table 4 then reports the results from estimating equation 5. In these results, January is used as the start date because it preceded any speculation of possible capital gains tax cuts. September is employed as the end month since the final legislation was passed on August 1, and we wanted to estimate a model that allowed sufficient time for the market to incorporate the information about the tax change into its valuations. However, we did experiment with a number of other event horizon windows, none of which yielded results significantly different from those reported in table $4 .^{18}$

The significantly negative $\beta_{7}$ coefficient of -0.146 indicates that acquisitive UPREITs had materially lower share price appreciation between January and September of 1997 than did acquisitive REITs over the same period, all measured relative to 1996 and to non-acquisitive REITs and UPREITs. Recall that our calibration of the potential cost of the capital gains tax change to UPREITs could be as much as 9.7 percent times the leverage scaling factor. The large amount of capitalization into UPREIT share prices that we find suggests that UPREITs capture most of the benefit of the tax subsidy and the impact on equity is magnified by leverage and possibly other factors. However, while we can reject the null of no share price effect, the standard error of the estimate is such that we cannot distinguish between full or partial capitalization.

\footnotetext{
${ }^{18}$ Moving the ending month back to October or November had virtually no effect. Moving the starting month back to February or March or the ending month forward to August or July reduced the estimated effect by a small and statistically insignificant amount. This pattern is consistent with the slow revelation of news during the legislative debate.

We also tested for differences in returns around short periods when we expect news was released. Those results are mixed. This differs from Lang and Shackelford (1999) who find that their effect appears within a one-week
} 
Our specification also allows non-acquisitive UPREIT and REIT appreciation to vary. The results in column one indicate there was little relative movement for them between 1996 and 1997. For example, the small estimated value of -0.017 for the $\beta_{2}$ coefficient on the 1997 year dummy indicates that traditional, non-acquisitive REITs did not experience any materially different growth over January to September 1997 than they did during the same period in 1996. In addition, the estimated coefficient on $\beta_{3}$ indicates that non-acquisitive UPREITs had only marginally slower growth in 1997 relative to 1996 than did REITs, as their share prices declined a statistically insignificant 1.6 percent more. Acquisitive REITs performed somewhat better relative to non-acquisitive REITs in $1997\left(\beta_{5}\right)$, with a 4.7 percent higher return than in 1996, but the standard error is such that we cannot distinguish this effect from zero either. $^{19}$

The remaining coefficients suggest that non-acquisitive UPREITs had higher average share price growth than non-acquisitive REITs in 1996. The estimate for $\beta_{1}$ indicates that UPREITs' share prices increased by 6.7 percent relative to REITs between January and September of 1996. Acquisitive REITs did not appreciate more than non-acquisitive REITs on average in 1996 ( $\beta_{4}$ is -0.023 and insignificantly different from zero). The results for $\beta$ 6 show that there is little or no difference in returns for acquisitive versus non-acquisitive UPREITs in 1996.

In sum, our main finding is one of substantial capitalization into share price of the difference in the after-tax cost of investing. The evidence suggests that in 1997 at least, acquisitive UPREITs, not building sellers, captured much of the benefit associated with the ability to defer capital gains taxes on

window, but their larger sample size may provide additional power in their regression.

${ }^{19}$ The results presented below in Table 5 for comparisons with 1995 and between 1995 and 1996 indicate there were differences in relative price appreciation among non-acquisitive firms in other years. While our identification strategy controls for these types of relative appreciation changes, the fact that virtually all the share price movement between 1996 and 1997 is coming through the only channel relevant to the capital gains rate reduction does make for an easier interpretation. 
property transactions with such firms. We believe that by comparing acquisitive UPREITs to acquisitive REITs, our results are prevented from being driven by spurious movements in the real estate or REIT markets. However, the latter proposition can be tested, and we do so in the next subsection, where it turns out that the capitalization result holds up well.

\section{d. Sensitivity to alternative specifications}

One possibility that could affect our estimated coefficients is miscategorizing a company as acquisitive. A company could have had a low $\mathrm{R} / \mathrm{V}$ due to expected reductions in operating expenses or upwardly sloping rent schedules rather than from high expected future purchases. This miscategorization would bias our estimated capitalization towards zero since we do not expect share prices for companies that have different operating capabilities or higher expected rent rollovers to change differentially with the capital gains tax change. To test for this possible bias, we also categorized companies that had above-median gross real estate asset growth in 1995 as 'acquisitive,' figuring that historical acquisitiveness is a reasonable proxy for $\mathrm{A} / \mathrm{V}$. Eighty-nine companies were classified the same way by both the asset growth and rent-to-value measures, 39 as acquisitive and 50 as not acquisitive. We eliminated the 40 companies that were classified as acquisitive under one measure and not acquisitive under the other and repeated the analysis. The estimated coefficients based on this sample are reported in column 2 of Table 4 . In every case, the results are substantively unchanged from the previous estimates, although the standard errors increase due to the reduced sample size. The estimated capitalization is virtually unchanged by eliminating the 40 potentially indeterminate companies.

Table 5 then reports the results from specifications that use non-tax years for comparison purposes and adjust the standard errors for possible correlation in the residuals across observations. Since table 4 demonstrated that the definition of acquisitive has virtually no impact on the results, we 
report findings only for our first definition of acquisitiveness, $\mathrm{R} / \mathrm{V}$.

The first column of table 5 presents results from comparing two years in which the capital gains tax did not change--1995 and 1996. If our identifying assumption -- namely, that benchmarking the performance of acquisitive UPREITs against that of non-acquisitive UPREITs and REITs of both types controls for all non-capital gains tax factors--we should not find any differential returns in 1996 relative to 1995 since no change in the relative tax subsidy took place. Indeed, the estimated coefficient on the interaction term is negligible, at 0.007 (0.089).

The specification reported in Column 2 tests the possibility that some spurious event happened in 1996 to increase the relative price of acquisitive UPREITs. If that were the case, we would erroneously find capitalization when we compared 1996 and 1997 returns. However, benchmarking 1997 returns against those from 1995 would avoid any problems due to 1996 being an 'odd' year. Since our estimated coefficient on the relative return difference for acquisitive UPREITs is -0.139 (0.070), indistinguishable from the point estimate when we compared 1996 and 1997, it suggests again that our identification strategy is sound. ${ }^{20}$

Another potential worry is that shocks to stock prices are not independent across the 129 companies in our sample. If, for example, there were a high correlation in the residuals across UPREITs since their returns are affected by common factors, we could be overstating the statistical significance of our results. Consequently, throughout this table we report standard errors that are corrected for general correlation in the residuals across observations. Even though this approach is

\footnotetext{
${ }^{20}$ Without controlling for acquisitiveness, returns for UPREITs relative to REITs appear to vary from year to year absent any change in the tax code. Overall UPREIT returns relative to those of REITs were low in 1996, relative to 1995 and 1997. The returns were approximately equal in 1995 and 1997. Simply comparing UPREITs to REITs would show a decline in UPREIT share values in 1997 relative to 1996 (and no difference from 1995 to 1997). However, comparing acquisitive and non-acquisitive firms as we do here completely controls for the differential returns over time for UPREITs relative to REITs.
} 
relatively inefficient, our estimate of $\beta_{7}$ in column 2 is still statistically significant at standard confidence levels. However, when we correct the standard errors in the specification in column three, which repeats the estimation over the 1996 and 1997 time period, the t-statistic falls to -1.5. In an attempt to gain some statistical power, we pool the 1995, 1996 and 1997 data in the fourth column, restricting the estimated coefficients to be the same in 1995 and 1996. Since the estimated coefficients do not vary much between 1995 and 1996 (column one), we believe this is a reasonable approach. In this case, the estimated coefficient, $\beta_{7}$, again is statistically significant and is no different than our baseline estimate at $-0.143(0.072)$.

Table 6 further augments the specification in table 4 by incorporating additional explanatory variables that might be varying over time in a way that would affect acquisitive UPREIT share prices relative to acquisitive REITs and others. ${ }^{21}$ This table suggests that the results regarding relative UPREIT share price growth in 1997 versus 1996 are quite robust to including a variety of covariates.

One potential explanation for our results is differences in beta. If acquisitive UPREITs have higher betas than other companies and 1997 was a worse year for market excess returns than 1996 or 1995, then swings in UPREIT share prices should exceed those for REITs. This would lead to a relative decline in UPREIT share prices in 1997 but a relative rise in 1996. The results in column one of Table 6 suggest this is not the case. Not only do differences in systematic risk not reduce the capitalization effect of interest here, but beta (and its interaction with the 1997 tax event window) do not play a meaningful independent role in explaining relative return performance. ${ }^{22}$ This result should not be

\footnotetext{
${ }^{21}$ Given that our key finding retains its statistical significance when allowing for correlation across observations, corrected standard errors are not reported here to better facilitate comparison with the results in Table 4.

${ }^{22}$ Beta was estimated for each firm via a single factor market model. Monthly return data were used from anytime since 1992. Some firms have as few as twelve observations, with others having as many as 72 . We also estimated a specification with the difference between the market return and the risk free return (compounded monthly from January-September in 1996 and 1997) on the right-hand side in lieu of beta and its interaction. Once again, the
} 
particularly surprising since the market sector mix of properties is very similar among REITs and UPREITs and among acquisitive and non-acquisitive firms. Since betas almost certainly are more affected by the segment of the real estate industry that the firm's properties are in than by corporate structure or strategy, one should not expect betas to have much explanatory power for the difference in returns.

Another possible contaminating factor arises from the possibility that UPREITs may have changed their dividend payout ratios over time in a way that traditional REITs did not. Since share prices reflect dividend payments, that could induce a differential change between UPREIT and REIT share prices. Column 2's results show that companies with higher dividend yields command higher share prices. However, including this variable has little effect on the relative growth of acquisitive UPREIT share prices -- the estimated coefficient on the interaction term increases slightly in magnitude to -0.165 (0.071). Since REITs have little control over how much of their taxable income they pay out in the form of dividends, this result also is not surprising. ${ }^{23,24}$

\section{e. Controlling for Fama-French factors in a time series specification}

capitalization effect was unaffected by including this covariate.

\footnotetext{
${ }^{23}$ This result also helps highlight that our key capitalization effect probably is not driven by the same forces reported in Lang and Shackelford (1999). In their work, share prices of companies with high dividend yields fell with capital gains tax rates, presumably because the after-capital-gains-tax cost of retaining earnings would be higher for a shareholder who planned on selling his stock on the secondary market. If UPREITs had higher dividend yields than REITs, perhaps because properties exchanged for OP units carry over low tax bases and thus cannot be redepreciated, then the effect of capital gains taxes on secondary trading could conceivably explain our finding. However, including dividend yield should control for this effect. The fact that incorporating it does not make any difference in our result suggests that our original research design adequately controls for this possible source of contamination.

${ }^{24}$ We have also estimated specifications that control for the fraction of shares owned by insiders and institutions, the vintage of the company (measured by the years since the firm' s IPO), lagged measures of the debt/asset ratio and return on assets, and the company size proxied by the gross value of the company's properties at the end of 1995. Only the last had an estimated coefficient that was statis tically different from zero and none had more than a slight effect on the estimated capitalization into UPREIT share prices.
} 
Our final table reports the results from estimating a time series test of our capitalization hypothesis. We try this approach for three reasons. First, we would like to examine whether other factors such as those introduced by Fama and French (1993) could be driving our measured drop in return for acquisitive UPREITs in 1997. Second, if one truly believed that share price returns within REITs or UPREITs were not independent, then the most conservative statistical assumption would be to assume the residuals were perfectly correlated and group them together as one observation. Finally, we would like to make sure that our strategy of computing returns as the growth in the monthly average price is not driving our results, so we use monthly returns (first day to last day) in a time series context.

The first column of table 7 addresses the latter two points. The left-hand-side variable is the difference between the returns of four value-weighted stock indices: the monthly return on an index of acquisitive UPREITs minus the monthly return on an index of acquisitive REITs, all minus the difference in monthly returns between non-acquisitive UPREITs and non-acquisitive REITs. The weights for the indices are the firms' market capitalizations on January 3, 1995. We have 36 monthly observations, covering January 1995 through December 1997.

On the right hand side, we include an indicator variable for January through September 1997, when the capital gains tax change was under discussion or being implemented. The estimated coefficient, -0.016 (0.007), implies that during the tax change window acquisitive UPREITs had a 1.6 percentage point lower return each month, and the effect is different from zero at the 96 percent confidence level. Grossing up the monthly relative return yields a nine month return that was 14.4 percentage points lower than it would have been in the absence of the tax change. ${ }^{25}$

In the second column of table 7, we add the three Fama-French factors--the market factor, the

\footnotetext{
${ }^{25}$ This result is not mechanically the same as the one reported in table 4 since the time series estimates incorporate data from October through December of each year while the earlier specifications omitted those months.
} 
book-to-market factor (HML), and the size factor (SMB) ${ }^{26}$ Note that the estimated coefficient on the period surrounding the capital gains tax change is virtually unchanged and is still significant at the 94 percent confidence level. None of the Fama-French factors have a statistically significant effect on the difference in returns, indicating that our identification strategy successfully controls for other market factors as well.

\section{f. Why isn't every REIT an UPREIT?}

Given that the capital gains tax deferral appears to benefit the owners of UPREITs rather than building sellers, it may seem surprising that all real estate companies do not form UPREITs. Since the stock market rewards the capital gains benefits of the UPREIT structure, why not simply switch organizational form and thus obtain higher share valuations?

First, the UPREIT structure is not free. Aside from the cost of initially converting between organizational forms, there is a potential conflict of interest and a loss of flexibility inherent in the structure. The conflict of interest arises from the different capital gains tax bases of the owners of the operating partnership units and the shareholders. The tax basis for a unit holder that received OP units in exchange for buildings is the tax basis of the original properties. Thus, if the building seller received $\$ 20$ million in partnership units for a property with a tax basis of $\$ 1$ million, his tax basis is $1 / 20$ of the value of each partnership unit at the time of issuance. However, shareholders have much higher capital gains tax bases since the tax basis for a share is the share value at the time of purchase. Since the contributors of the properties typically control substantial portions of the voting rights, the unit holders are potentially willing to engage in a deal that is more lucrative for themselves at the expense of the

\footnotetext{
${ }^{26} \mathrm{We}$ are grateful to Eugene Fama for providing updated series on these factors. Fama and French (1993) provides the details on how these variables are constructed. The market factor is measured as the excess of the market return over the risk-free rate. The HML series reflects the risk factor on returns related to book-to-market equity. It is the difference in the average of return on high versus low book-to-market equity portfolios that have roughly the same weighted average size. The SMB series is meant to mimic the risk factor in returns related to size. It captures the difference between the returns on large and small stock portfolios that have roughly the same weighted average book-to-market equity.
} 
stockholders. This conflict of interest can depress the share price. In addition, the flexibility of the UPREIT with respect to the disposition of properties is reduced. Since unit holders must pay capital gains taxes when the properties they contributed are sold, lock-outs often are placed on the properties preventing their sale for a period of time. Or, unit holders can exercise their voting rights to prevent property sales that would create adverse tax consequences for them.

These conflicts of interest and reductions in flexibility increase the cost of using the UPREIT structure, helping explain why many companies choose to remain REITs. A recent working paper by Gentry, Kemsley, and Mayer (1999) suggests that switching to UPREIT status depresses a company's share price. However, one would then expect that only those companies that would obtain the most benefit from the UPREIT structure would adopt it. Such companies naturally would be ones who plan to acquire relatively large amounts of appreciated properties. If that type of selection were occurring, UPREITs would be more acquisitive relative to REITs.

However, in our sample, REITs and UPREITs appear to be equally acquisitive, ex ante. As reported in the previous section, half of all acquisitive companies, and 35 percent of non-acquisitive companies, are UPREITs. We suspect that the initial benefit of becoming an UPREIT, namely that the original property owners can access equity capital markets without incurring a capital gains tax on their existing properties -- induced many real estate companies to adopt the structure even if they planned no further acquisitions. While adopting the UPREIT structure might lower the share price relative to that for a regular REIT, presumably that factor is outweighed by the tax benefits for the people who are contributing properties at the time. The ability to enable property sellers to defer capital gains taxes offsets some of the reduction in share price. In that case, lowering the capital gains tax rate would 
decrease UPREIT share prices yet further. ${ }^{27}$ In other words, one possible explanation is that a small increase in the capital gains tax subsidy would provide a benefit to UPREITs on the margin, but switching from REIT to UPREIT status would still lead to a drop in share prices. ${ }^{28}$

\section{Conclusion}

By comparing the performance of two organizational forms of publicly-traded real estate companies, we are able to estimate the effect of the capital gains tax rate reduction in TRA97 on the share prices of UPREITs while holding all other industry-level and time-varying changes constant. The result gives insight into the classic question of the asset price incidence of taxes while minimizing the identification problems of previous work. In addition, we are able to provide new evidence on a corporate-level subsidy to investment, in contrast to much of the literature on tax capitalization which focuses on shareholder-level effects.

In our preferred specification, we find that the capital gains tax rate changes in TRA97 led to a 14 percent decline in the share price of acquisitive UPREITs relative to REITs and non-acquisitive UPREITs, all relative to the same time period in 1996. By comparing acquisitive real estate companies to less-acquisitive ones, we are able to prevent our results from being driven by spurious movements in property prices. These results are robust to changes in the sample time frame and to the inclusion of various alternative explanatory variables. When we re-estimated our specification during a time period when tax rates did not change, we found no effect, increasing our confidence in the results.

Overall, our results suggest that much of the economic incidence of the tax subsidy is borne by

\footnotetext{
${ }^{27}$ Consistent with this story, the bulk of UPREITs were created as such and did not switch from REIT status. This would also explain why the option to switch from REIT to UPREIT status is not valuable -- it is out of the money unless there is a large property holder that wishes to avoid gains tax.

${ }^{28}$ For those companies that do switch structure, it appears that they were less likely to do so in 1997. Six companies adopted the downREIT structure in 1996 while only two did so in 1997. Of those two, one switched in mid April, still early in the tax change debate.
} 
the buyer of properties, the UPREITs, even though the legal incidence is on the property seller. It is also clear that a tax-induced reduction in the return to property investing for UPREITs was reflected in their share prices. A natural extension to this work is to investigate the effects of this tax change on real investment. If the after-tax cost of purchasing properties rose for UPREITs relative to REITs, did UPREITs decrease the amount of their acquisitions relative to REITs? ${ }^{29}$ Using our data set of property acquisitions, we are pursuing the answer to this question.

\footnotetext{
${ }^{29}$ This research would contribute to the debate on whether tax policy affects real investment. See Auerbach and Hassett (1992), Cummins, Hassett, and Hubbard (1994), and Goolsbee (1998).
} 


\section{References:}

Auerbach, Alan and Kevin Hassett. "Tax Policy and Business Fixed Investment in the United States," Journal of Public Economics, v. 47 (March 1992), pp. 141-170.

Constantinides, George. "Capital Market Equilibrium with Personal Tax,” Econometrica, vol. 51 (May 1983), pp. 611-636.

Cummins, David, Kevin Hassett, and R. Glenn Hubbard. "A Reconsideration of Investment Behavior Using Tax Reforms as Natural Experiments," Brookings Papers on Economics Activity, v. 2 (1994), pp. 1-59.

Cutler, David. "Tax Reform and the Stock Market: An Asset Price Approach," American Economic Review, v.78 no.5 (December 1988), pp.1107-1117.

Eissa, Nada. "Taxation and Labor Supply of Married Women: The Tax Reform Act of 1986 as a Natural Experiment," NBER Working Paper \#5023, (February 1995).

Fama, Eugene and Kenneth French. "Common Risk Factors in the Returns on Stocks and Bonds," Journal of Financial Economics, v. 33, no. 1 (February 1993): 3-56.

Gentry, Bill, Deen Kemsley, and Chris Mayer. "Are Dividend Taxes Capitalized into Share Prices: Evidence from Real Estate Investment Trusts," Mimeo, University of Pennsylvania, (September 1999).

Goolsbee, Austan. "Investment Tax Incentives, Prices, and the Supply of Capital Goods," Quarterly Journal of Economics, v.113 no.1 (February 1998), pp.121-148.

Gruber, Jonathan. "The Incidence of Mandated Maternity Benefits," American Economic Review, v.84 no.3 (June 1994), pp. 622-641.

Gruber, Jonathan and James Poterba. "Tax Incentives and the Decision to Purchase Health Insurance: Evidence from the Self-Employed," Quarterly Journal of Economics, v.109 (August 1994), pp. 701-733.

Harris, Trevor, R. Glenn Hubbard, and Deen Kemsley. "The Share Price Effects of Dividend Taxes and Tax Imputation Credits," Mimeo, Columbia University (May 1999).

- and Deen Kemsley. "Dividend Taxation in Firm Valuation: New Evidence." Mimeo, Columbia Business School (May 1999).

Klein, Peter. "The Capital Gain Lock-in Effect and Equilibrium Returns," Journal of Public Economics, v.71 no. 3 (March 1999), pp.355-378. 
Landsman, Mark, and Douglas Shackelford. "The Lock-in Effect of Capital Gains Taxes: Evidence from the RJR Nabisco Leveraged Buyout," National Tax Journal, v.48 (1995), pp. 245259.

Lang, Mark and Douglas Shackelford. "Capitalization of Capital Gains Taxes: Evidence from Stock Price Reactions to the 1997 Rate Reduction," Journal of Public Economics, v.76 (April 2000), pp. 69-85.

Poterba, James, and Scott Weisbenner. "Capital Gains Tax Rules, Tax Loss Trading, and Turn-of-theYear Returns.” Journal of Finance, forthcoming February 2001.

Stiglitz, Joseph. "Some Aspects of the Taxation of Capital Gains," Journal of Public Economics, vol. 21 (July 1983), pp. 257-294.

Summers, Lawrence. "Taxation and Corporate Investment: A q-Theory Approach," Brookings Papers on Economic Activity, (1981) 1, pp. 67-127. 


\section{Table 1: Taxpayer Relief Act of 1997 Timeline of Major Headlines}

First week of

February, 1997

February 13

February 23

March 2

Mid-April

April 30

May 3

May 7

Rest of May

June 10

June 14

June 18

June 27

June 30

July 23

July 29

August 1
Clinton says he might be willing to cut capital gains taxes to reach a budget compromise, but the Administration's preference is for a capital gains tax increase. Republicans want to lower rate to below 20 percent.

Senator Trent Lott says that Democrats' opposition to capital gains tax cuts may be breaking down.

The New York Times reports that Democrats have reduced their opposition to capital gains tax cuts.

Clinton Administration and Congress are still debating potential cuts.

Republican budget negotiators keep heat on Administration to agree to reduce capital gains taxes

$\mathrm{CBO}$ reduces estimated size of budget deficit

Agreement reached to reduce capital gains tax rates, the size of the cuts is to be determined

Announcement that capital gains tax cuts would be effective May 7

Republicans deciding whether to cut capital gains taxes or income taxes

Archer proposes reducing capital gains tax to 20 percent

House Ways and Means Committee approves Archer plan

Senate proposes capital gains tax cut to 20 percent

House passes capital gains tax cut

Clinton wants 27.72 maximum capital gains tax rate

House and Senate Republicans reach agreement on bill

Clinton Administration and Republicans reach consensus

House and Senate approve TRA97

Based on articles from the New York Times and the Wall Street Journal. 


\begin{tabular}{lcc}
\hline \hline & $\begin{array}{c}\text { Number } \\
\text { Deleted }\end{array}$ & Total \\
\cline { 2 - 3 } & & 202 \\
$\begin{array}{l}\text { Number of REITs as of the first quarter of 1998, according to } \\
\text { SNL DataSource: }\end{array}$ & 46 & 156 \\
-REITs that were formed after January 2, 1996: & 2 & 154 \\
-REITs with no CRSP matches: & 12 & 142 \\
-Remaining REITs that are not equity REITs: & 11 & 131 \\
-REITs that adopted UPREIT structure during sample & 2 & 129 \\
-REITs with indeterminate IPO date & $\mathbf{7 3}$ & $\mathbf{1 2 9}$ \\
\cline { 2 - 3 } Total: &
\end{tabular}

${ }^{1}$ Eleven companies were dropped from the sample because they adopted an UPREIT or DownREIT structure between January 2, 1996 and December 31, 1997. Those companies are: American Industrial Properties REIT, Asset Investors Corporation, Boddie-Noell Properties, Inc, Brandywine Realty Trust, Burnham Pacific Properties, Inc, Franklin Select Property Trust, Ramco-Gershenson Properties Trust, Realty ReFund Trust, and Vornado Realty Trust. 
Table 3: Sample Means

\begin{tabular}{lcc}
\hline \hline & Traditional REITs & UPREITs \\
\cline { 2 - 3 } Share Price & 25.49 & 26.39 \\
& {$[9.73]$} & {$[8.99]$} \\
Annual Dividends Declared & 1.59 & 1.70 \\
& {$[1.26]$} & {$[1.13]$} \\
Years since IPO & 18.59 & 6.10 \\
& {$[13.11]$} & {$[5.66]$} \\
\% Insider Ownership & 8.89 & 12.41 \\
& {$[8.35]$} & {$[10.32]$} \\
\% Institutional Ownership & 35.08 & 58.28 \\
& {$[16.25]$} & {$[18.05]$} \\
Debt/Asset Ratio & 0.42 & 0.46 \\
Shares Outstanding (000) & {$[0.16]$} & {$[0.16]$} \\
Gross Property Value (000) & 38,354 & 33,537 \\
(Q4 1995) & {$[22,844]$} & {$[25,860]$} \\
Weight (Market Cap. on & 735,031 & 818,630 \\
Jan 2, 1996 / 100,000) & {$[412,857]$} & {$[571,479]$} \\
Number of Companies & 3,616 & 3,284 \\
Number of Observations & {$[3,708]$} & {$[2,798]$} \\
\hline \hline
\end{tabular}

Notes: Standard deviations are in square brackets. Observations are for all trading days in 1996 and 1997 for 129 publicly-traded real estate companies. All rows except for the last three are weighted by the reported weight variable. 
Table 4: Share Prices Respond for 'Acquisitive' UPREITs

\begin{tabular}{lcc}
\hline \hline & & $\begin{array}{c}\text { 'Acquisitive' Means } \\
\text { Below-Median } \\
\text { Rent/Value Ratio } \\
\text { and Above-Median }\end{array}$ \\
& $\begin{array}{c}\text { 'Acquisitive' Means } \\
\text { Below-Median } \\
\text { Rent/Value Ratio in 1995 }\end{array}$ & $\begin{array}{c}\text { Gross Real Estate Growth } \\
\text { in 1995 }\end{array}$ \\
\cline { 2 - 3 } & $(1)$ & $(2)$ \\
\cline { 2 - 3 } & -0.017 & 0.028 \\
UPREIT dummy $\left(\beta_{1}\right)$ & $(0.042)$ & $(0.053)$ \\
Acquisitive dummy $\left(\beta_{4}\right)$ & 0.067 & 0.095 \\
Acquisitive x 1997 $\left(\beta_{5}\right)$ & $(0.037)$ & $(0.048)$ \\
Acquisitive x UPREIT & -0.023 & 0.012 \\
$\left(\beta_{6}\right)$ & $(0.039)$ & $(0.049)$ \\
UPREIT x 1997 $\left(\beta_{3}\right)$ & 0.047 & -0.008 \\
Acquisitive x UPREIT & $(0.055)$ & $(0.070)$ \\
x 1997 $\left(\beta_{7}\right)$ & 0.009 & -0.023 \\
Adjusted R & $(0.052)$ & $(0.065)$ \\
\hline \hline
\end{tabular}

Notes: The left-hand-side variable is $\log$ (average share price in September)-log(average share price in January). Standard errors are in parentheses. A constant term is estimated but not reported. In column 1, the number of observations is 258, representing 129 companies over 1996 and 1997. In column 2, 40 companies that have above-median rent-value ratios or below-median gross real estate growth, but not both, are eliminated. Regressions are weighted by each firm's market capitalization on January 2, 1996. 


\section{Table 5: Comparisons of Baseline Results with Other Years and Allowing for Correlation in the Residuals}

\begin{tabular}{|c|c|c|c|c|}
\hline & \multicolumn{4}{|c|}{ 'Acquisitive' Means Below-Median Rent/Value Ratio in 1995} \\
\hline & $\begin{array}{l}1995 \mathrm{vs} \\
1996\end{array}$ & $\begin{array}{c}1995 \mathrm{vs} \\
1997\end{array}$ & $\begin{array}{c}1996 \mathrm{vs} \\
1997\end{array}$ & $\begin{array}{c}\text { Pooled 95/96 } \\
\text { vs. } 1997\end{array}$ \\
\hline Dummy for second year $\left(\beta_{2}\right)$ & $\begin{array}{l}-0.048 \\
(0.059)\end{array}$ & $\begin{array}{l}-0.063 \\
(0.029)\end{array}$ & $\begin{array}{l}-0.017 \\
(0.052)\end{array}$ & $\begin{array}{l}-0.039 \\
(0.034)\end{array}$ \\
\hline UPREIT dummy $\left(\beta_{1}\right)$ & $\begin{array}{l}-0.037 \\
(0.031)\end{array}$ & $\begin{array}{l}-0.037 \\
(0.031)\end{array}$ & $\begin{array}{c}0.067 \\
(0.052)\end{array}$ & $\begin{array}{c}0.012 \\
(0.032)\end{array}$ \\
\hline Acquisitive dummy $\left(\beta_{4}\right)$ & $\begin{array}{c}0.031 \\
(0.028)\end{array}$ & $\begin{array}{c}0.031 \\
(0.028)\end{array}$ & $\begin{array}{l}-0.023 \\
(0.071)\end{array}$ & $\begin{array}{c}0.002 \\
(0.041)\end{array}$ \\
\hline Acquisitive $\mathrm{x}$ Year $2\left(\beta_{5}\right)$ & $\begin{array}{l}-0.056 \\
(0.080)\end{array}$ & $\begin{array}{l}-0.007 \\
(0.034)\end{array}$ & $\begin{array}{c}0.046 \\
(0.073)\end{array}$ & $\begin{array}{c}0.021 \\
(0.046)\end{array}$ \\
\hline Acquisitive $x$ UPREIT $\left(\beta_{6}\right)$ & $\begin{array}{c}0.012 \\
(0.041)\end{array}$ & $\begin{array}{c}0.012 \\
(0.041)\end{array}$ & $\begin{array}{c}0.009 \\
(0.074)\end{array}$ & $\begin{array}{c}0.016 \\
(0.045)\end{array}$ \\
\hline UPREIT x Year $2\left(\beta_{3}\right)$ & $\begin{array}{c}0.099 \\
(0.065)\end{array}$ & $\begin{array}{c}0.111 \\
(0.041)\end{array}$ & $\begin{array}{l}-0.016 \\
(0.059)\end{array}$ & $\begin{array}{c}0.062 \\
(0.042)\end{array}$ \\
\hline $\begin{array}{l}\text { Acquisitive } x \text { UPREIT } x \\
\quad \text { Year } 2\left(\beta_{7}\right)\end{array}$ & $\begin{array}{c}\text { 0.007 } \\
(\mathbf{0 . 0 8 9})\end{array}$ & $\begin{array}{l}-\mathbf{0 . 1 3 9} \\
(0.070)\end{array}$ & $\begin{array}{l}-0.146 \\
(0.098)\end{array}$ & $\begin{array}{l}-0.143 \\
(0.072)\end{array}$ \\
\hline $\begin{array}{l}\text { F-test that } 95-97 \text { is equal to } \\
\text { 95-96: }\end{array}$ & \multicolumn{2}{|c|}{$\begin{array}{c}\mathrm{F}=2.28 \\
(\mathrm{p}=0.1317)\end{array}$} & & \\
\hline Number of observations: & 240 & 240 & 256 & 360 \\
\hline $\mathrm{R}^{2}$ & 0.0701 & 0.1104 & 0.0935 & 0.0484 \\
\hline
\end{tabular}

Notes: The left-hand-side variable is $\log$ (average share price in September)-log(average share price in January). Standard errors, corrected for general correlation in the residuals across observations, are in parentheses. A constant term is estimated but not reported. Regressions are weighted by each firm's market capitalization on January 3, 1995. 


\begin{tabular}{|c|c|c|}
\hline & (1) & (2) \\
\hline 1997 dummy $\left(\beta_{2}\right)$ & $\begin{array}{l}-0.035 \\
(0.107)\end{array}$ & $\begin{array}{c}-0.024 \\
(0.042)\end{array}$ \\
\hline UPREIT dummy $\left(\beta_{1}\right)$ & $\begin{array}{c}0.060 \\
(0.038)\end{array}$ & $\begin{array}{c}0.042 \\
(0.037)\end{array}$ \\
\hline Acquisitive dummy $\left(\beta_{4}\right)$ & $\begin{array}{l}-0.026 \\
(0.039)\end{array}$ & $\begin{array}{c}-0.054 \\
(0.039)\end{array}$ \\
\hline Acquisitive x $1997\left(\beta_{5}\right)$ & $\begin{array}{c}0.048 \\
(0.055)\end{array}$ & $\begin{array}{c}0.066 \\
(0.054)\end{array}$ \\
\hline Acquisitive x UPREIT $\left(\beta_{6}\right)$ & $\begin{array}{c}0.008 \\
(0.052)\end{array}$ & $\begin{array}{c}0.051 \\
(0.051)\end{array}$ \\
\hline UPREIT x $1997\left(\beta_{3}\right)$ & $\begin{array}{l}-0.013 \\
(0.054)\end{array}$ & $\begin{array}{l}-0.013 \\
(0.052)\end{array}$ \\
\hline Acquisitive $x$ UPREIT x $1997\left(\beta_{7}\right)$ & $\begin{array}{l}-0.147 \\
(0.073)\end{array}$ & $\begin{array}{l}-0.165 \\
(0.071)\end{array}$ \\
\hline Beta & $\begin{array}{l}-0.059 \\
(0.079)\end{array}$ & \\
\hline Beta x 1997 & $\begin{array}{c}0.018 \\
(0.112)\end{array}$ & \\
\hline Dividend yield & & $\begin{array}{c}1.247 \\
(0.326)\end{array}$ \\
\hline Number of observations & 258 & 256 \\
\hline Adjusted $\mathrm{R}^{2}$ & 0.064 & 0.117 \\
\hline
\end{tabular}

Notes: The left-hand-side variable is $\log$ (average share price in September)-log(average share price in January). Standard errors are in parentheses. A constant term is estimated but not reported. Regressions are weighted by each firm's market capitalization on January 2, 1996. 
Table 7: Incorporating Fama-French Factors in a Time Series Estimation

\begin{tabular}{lcc}
\hline \hline & $(1)$ & $(2)$ \\
\hline $\begin{array}{l}\text { Indicator variable for the period when the tax } \\
\text { change was under discussion }\end{array}$ & -0.0160 & -0.0159 \\
$r_{m}-r_{f}$ & $(0.0074)$ & $(0.0081)$ \\
& & 0.0001 \\
Size factor & & $(0.0015)$ \\
& & -0.0001 \\
Book-to-market factor & & $(0.0014)$ \\
& & 0.0004 \\
Constant & 0.0031 & $(0.0021)$ \\
Adjusted $\mathrm{R}^{2}$ & $(0.0037)$ & 0.0028 \\
\hline
\end{tabular}

Notes: The left-hand-side variable is (monthly return on an index of acquisitive UPREITs - monthly return on an index of acquisitive REITs) - (monthly return on an index of non-acquisitive UPREITs monthly return on an index of non-acquisitive REITs). The indices are constructed using weighted returns where the weights are each firm's market capitalization on January 3, 1995. There are 36 monthly observations covering January 1995 through December 1997. The indicator variable takes the value of one in January through September 1997 and is zero otherwise. Standard errors are in parentheses. 
Figure 1: Creation of UPREITs vs. Traditional REITs, by Year

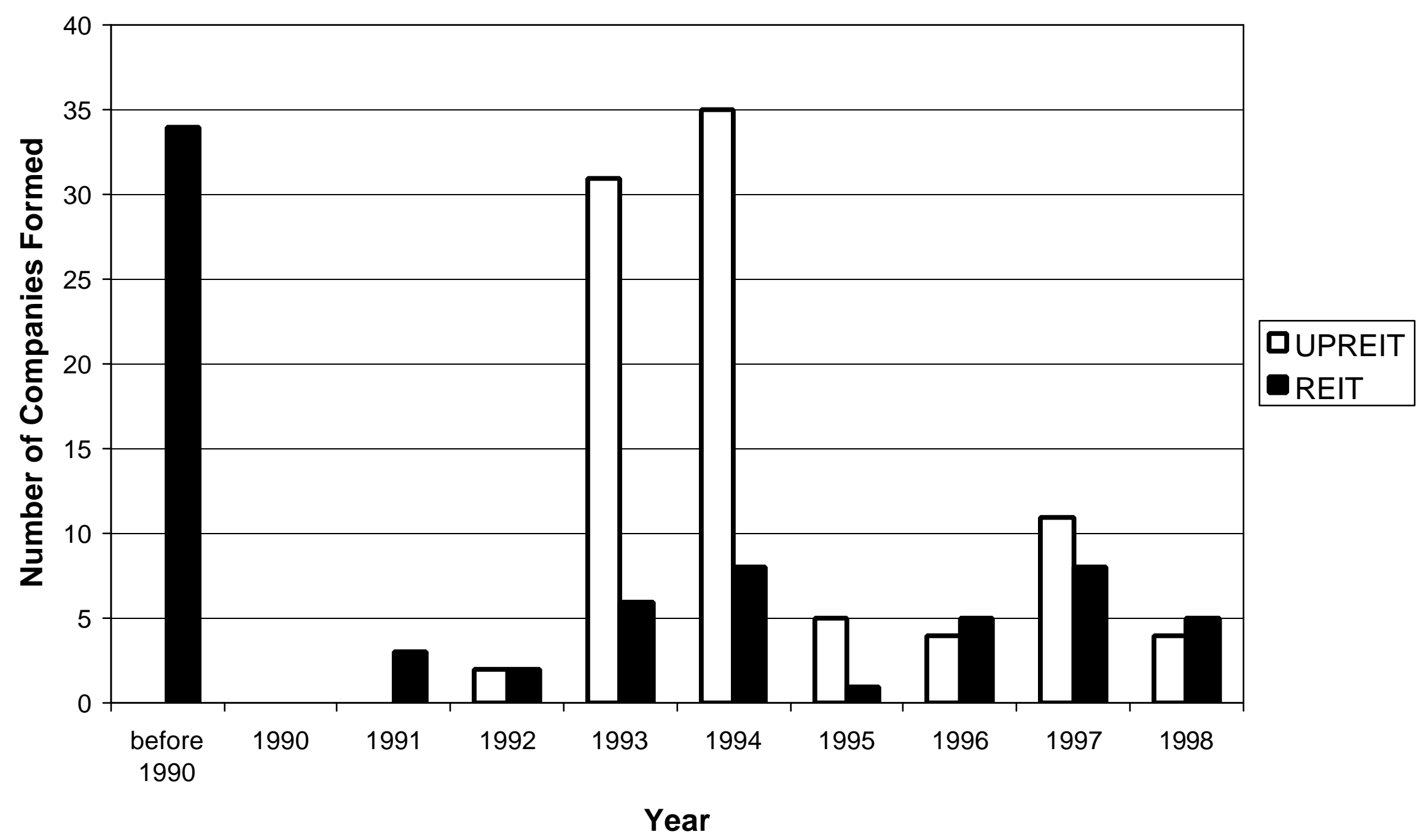




\section{Appendix:}

An UPREIT modifies a publicly-traded REIT by melding it with an operating partnership.

Figure 1A illustrates how a simple UPREIT structure might be set up. The operating partnership owns all the properties directly while the publicly traded portion is a partner. The UPREIT's equity consists of stock, which are shares in the REIT portion, and operating partnership (OP) units, which are shares in the partnership. UPREIT shareholders do not own the underlying real estate directly, but indirectly through the REIT's ownership of the operating partnership. Other equity investors may only own OP units directly. Typically, one OP unit is convertible into one share of common stock and receives the same dividend payments. In order to cash out, a unit holder simply converts her OP units to common stock and sells the shares. Capital gains taxes are not paid on the portion of a property's value that is received in OP units. When the OP units are sold, however, gains tax must be paid on them, with the tax basis being carried over from the original property.

\section{Figure 1A: The UPREIT Structure.}

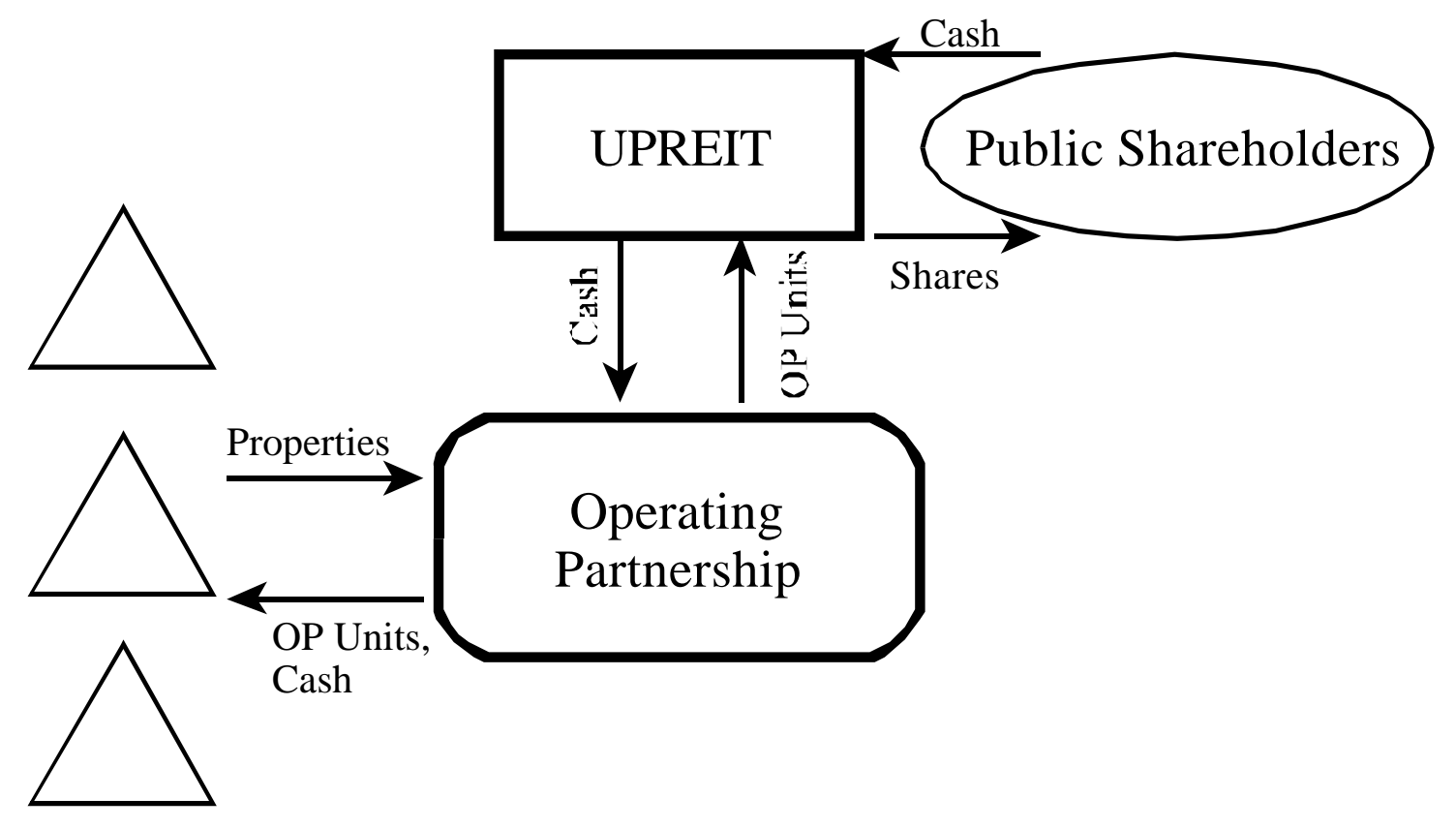

Building

Sellers 